\title{
Message From the Editor-in-Chief
}

\section{Dear Colleagues}

On behalf of the Circulation Journal, I would like to let you know about the official 2008 impact factor, our new International Associate Editors, and the Circulation Journal papers (2006-2007) most frequently quoted in 2008 , that substantially contributed to the 2008 impact factor of the Journal.

\section{The Official 2008 Impact Factor}

We are pleased to inform that Circulation Journal has earned an official 2008 Impact Factor (IF) of 2.387. This official ranking also places Circulation Journal 32nd among the 78 journals in the Cardiac \& Cardiovascular Systems category in the 2008 Journal Citation Reports Science Edition. I would like to congratulate Dr Matsuzaki, the immediate past Editor-in-Chief, who served until June 2008, all the members of the Editorial Committee, authors, reviewers, and all our readers for their great contributions to Circulation Journal.

\section{New International Associate Editors}

In order to facilitate the internationalization of Circulation Journal, the Editorial Team and the Board of the Japanese Circulation Society have decided to recruit internationally recognized researchers who are working abroad as new International Associate Editors. As you can see in the back front page of this month's issue of the Journal, the following 11 researchers have kindly agreed to work with us as Associate Editors, to enhance the scientific level of the Journal, and enhance our level of internationalization.

\begin{tabular}{lll}
\hline \multicolumn{1}{c}{ Name } & \multicolumn{1}{c}{ Institute } & \multicolumn{1}{c}{ Expertise } \\
\hline Masanori Aikawa & Harvard Medical School & Vascular biology \\
Alvaro Alonso & University of Minnesota & Epidemiology \\
Dominick J. Angiolillo & University of Florida & Coronary intervention \\
Shih-Ann Chen & National Yang-Ming Univ. & Arrhythmia, Catheter ablation \\
Karen Fagan & Univ. of South Alabama & Pulmonary circulation \\
Hyo-Soo Kim & Seoul National University & Regenerative medicine \\
Douglas L. Mann & Washington University & Heart failure \\
Seung-Jung Park & University of Ulsan & Coronary intervention \\
Junichi Sadoshima & Univ. Med. Dent. NJ & Molecular cardiology \\
Nanping Wang & Peking University & Vascular biology \\
Y. Joseph Woo & University Pennsylvania & Cardiac surgery \\
\hline
\end{tabular}

\section{Top 20 Most Frequently Quoted CJ Papers (2006-2007) in 2008}

The following papers, published in 2006-2007, were among the 20 most frequently quoted papers in 2008, thereby substantially contributing to the 2008 Impact Factor of the Journal (numbers in parentheses denote the number of quotations in 2008).

(1) (36) Ehara M, Surmely JF, Kawai M, Katoh O, Matsubara T, Terashima M, et al. Diagnostic accuracy of 64-slice computed tomography for detecting angiographically significant coronary artery stenosis in an unselected consecutive patient population-Comparison with conventional invasive angiography, 2006, 70, 564-571.

(2) (20) Ishikura K, Yamada N, Ito M, Ota S, Nakamura M, Isaka N, et al. Beneficial acute effects of Rho-kinase inhibitor in patients with pulmonary arterial hypertension, 2006, 70, 174-178.

(3) (16) Fujita K, Nishizawa H, Funahashi T, Shimomura I, Shimabukuro M. Systemic oxidative stress is associated with visceral fat accumulation and the metabolic syndrome, 2006, 70, 1437-1442.

(4) (15) Banach M, Rysz J, Drozdz J, Okonski P, Misztal M, Barylski M, et al. Risk factors of atrial fibrillation following coronary artery bypass grafting-A preliminary report, 2006, 70, 438-441.

(5) (14) Yasue H, Hirai N, Mizuno Y, Harada E, Itoh T, Yoshimura M, et al. Low-grade inflammation, thrombogenicity, and atherogenic lipid profile in cigarette smokers, 2006, 70, 8-13.

(5) (14) Jeong JW, Jeong MH, Yun KH, Oh SK, Park EM, Kim YK, et al. Echocardiographic epicardial fat thickness and coronary artery disease, 2007, 71, 536-539.

(7) (13) Oda E, Oohara K, Abe A, Veeraveedu PT, Watanabe K, Kato K, et al. The optimal cut-off point of C-reactive 
protein as an optional component of metabolic syndrome in Japan, 2006, 70, 384-388.

(7) (13) Ishikawa S, Kayaba K, Gotoh T, Nakamura Y, Kajii E. Metabolic syndrome and C-reactive protein in the general population-JMS Cohort Study, 2007, 71, 26-31.

(9) (11) Kubozono T, Miyata M, Ueyama K, Nagaki A, Otsuji Y, Kusano K, et al. Clinical significance and reproducibility of new arterial distensibility index, 2007, 71, 89-94.

(9) (11) Kajiguchi M, Kondo T, Izawa H, Kobayashi M, Yamamoto K, Shintani S, et al. Safety and efficacy of autologous progenitor cell transplantation for therapeutic angiogenesis in patients with critical limb ischemia, 2007, 71, 196-201.

(11) (10) NIPPON DATA80 Research Group. Risk assessment chart for death from cardiovascular disease based on a 19-year follow-up study of a Japanese representative population-NIPPON DATA80, 2006, 70, 1249-1255.

(11) (10) Takeishi Y, Niizeki T, Arimoto T, Nozaki N, Hirono O, Nitobe J, et al. Serum resistin is associated with high risk in patients with congestive heart failure-A novel link between metabolic signals and heart failure, 2007, $71,460-464$.

(13) (9) Yamawaki H, Iwai N. Mechanisms underlying nano-sized air-pollution-mediated progression of atherosclerosis-Carbon black causes cytotoxic injury/inflammation and inhibits cell growth in vascular endothelial cells, 2006, 70, 129-140.

(13) (9) Nemoto O, Kawaguchi M, Yaoita H, Miyake K, Maehara K, Maruyama Y. Left ventricular dysfunction and remodeling in streptozotocin-induced diabetic rats, 2006, 70, 327-334.

(13) (9) Hayasaki T, Kaikita K, Okuma T, Yamamoto E, Kuziel WA, Ogawa H, et al. CC chemokine receptor-2 deficiency attenuates oxidative stress and infarct size caused by myocardial ischemia-reperfusion in mice, 2006, $70,342-351$.

(13) (9) Ishikawa C, Tsutamoto T, Fujii M, Sakai H, Tanaka T, Horie M. Prediction of mortality by high-sensitivity C-reactive protein and brain natriuretic peptide in patients with dilated cardiomyopathy, 2006, 70, 857-863.

(13) (9) Arai M, Misao Y, Nagai H, Kawasaki M, Nagashima K, Suzuki K, et al. Granulocyte colony-stimulating factor-A noninvasive regeneration therapy for treating atherosclerotic peripheral artery disease, 2006, 70, $1093-1098$

(13) (9) Suzuki S, Kamihata H, Hata T, Hayashi F, Miura A, Yoshinaga M, et al. Success rate of implantation and mid-term outcomes of the sirolimus-eluting stent, 2007, 71, 15-19.

(13) (9) Marui A, Tabata Y, Kojima S, Yamamoto M, Tambara K, Nishina T, et al. A Novel approach to therapeutic angiogenesis for patients with critical limb ischemia by sustained release of basic fibroblast growth factor using biodegradable gelatin hydrogel-An initial report of the phase I-IIa study, 2007, 71, 1181-1186.

(20) (8) Shin DG, Yoo CS, Yi SH, Bae JH, Kim YJ, Park JS, et al. Prediction of paroxysmal atrial fibrillation using nonlinear analysis of the R-R interval dynamics before the spontaneous onset of atrial fibrillation, 2006, 70, 94-99.

(20) (8) Kosuge M, Kimura K, Kojima S, Sakamoto T, Ishihara M, Asada Y, et al. Sex differences in early mortality of patients undergoing primary stenting for acute myocardial infarction, 2006, 70, 217-221.

(20) (8) Inoue H, Nozawa T, Hirai T, Iwasa A, Okumura K, Lee JD, et al. Accumulation of risk factors increases risk of thromboembolic events in patients with nonvalvular atrial fibrillation, 2006, 70, 651-656.

(20) (8) Jinzaki M, Sato K, Tanami Y, Yamada M, Kuribayashi S, Anzai T, et al. Novel method of displaying coronary CT angiography-Angiographic view, 2006, 70, 1661-1662.

(20) (8) Fuke S, Maekawa K, Kawamoto K, Saito H, Sato T, Hioka T, et al. Impaired endothelial vasomotor function after sirolimus-eluting stent implantation, 2007, 71, 220-225.

(20) (8) Matsushita K, Yatsuya H, Tamakoshi K, Yang PO, Otsuka R, Wada K, et al. High-sensitivity C-reactive protein is quite low in Japanese men at high coronary risk, 2007, 71, 820-825.

(20) (8) Kawai S, Kitabatake A, Tomoike H, Takotsubo Cardiomyopathy Study Group. Guidelines for diagnosis of Takotsubo (ampulla) cardiomyopathy, 2007, 71, 990-992.

(20) (8) Itoh T, Mizuno Y, Harada E, Yoshimura M, Ogawa H, Yasue H. Coronary spasm is associated with chronic low-grade inflammation, 2007, 71, 1074-1078.

The Editorial Team looks forward to receiving manuscripts with high scientific impact from all over the world.

Hiroaki Shimokawa, MD, PhD

Editor-in-Chief

Circulation Journal 